\title{
River Water Contamination Resulting from the Mariana Disaster, Brazil
}

\author{
Meri Diana Strauss Foesch ${ }^{1}$ (1) 0000-0001-6290-7140 \\ Marcio Rocha Francelino ${ }^{1,2}$ (1) 0000-0001-8837-1372 \\ Pablo Azevedo Rocha ${ }^{3}$ (1) 0000-0001-9581-9622 \\ Adalberto Rodrigues Lira Gomes ${ }^{2}$ (1) 0000-0003-4137-8352
}

\begin{abstract}
Following a disruption on November 5, 2015, the Gualaxo do Norte and Carmo Rivers received iron tailings from the Fundão Dam in Mariana, Minas Gerais, which affected the water's physiochemical attributes. This study aimed to better understand the impact of this event by evaluating water quality variations, comparing results from previous studies and the limits established in the National Environmental Council (Conama), Resolution 357. For six months, water samples were collected monthly at six points, three in the Gualaxo do Norte River and three in the Carmo River. Turbidity, color, and dissolved metal values were recorded for thirty-six samples, and it was determined that the Gualaxo do Norte River had higher contamination levels than those established in the Conama Resolution 357. According to the results, this study recommends the development of specific analyses and a special water quality classification system.
\end{abstract}

Keywords: pollution, physicochemical characteristics, water quality, environmental monitoring, environmental impact.

\section{INTRODUCTION AND OBJECTIVES}

On November 5, 2015, a disruption of the Fundão Dam, which belongs to the company Samarco S.A. and is located in the municipality of Mariana in Minas Gerais (MG), caused what is considered to be the greatest environmental disaster in the history of Brazil. Approximately 34 million $\mathrm{m} 3$ of iron ore tailings were released into the Gualaxo do Norte, Carmo, and Doce Rivers, as well as into the Atlantic Ocean through the northern coastal area of Espírito Santo and southern Bahia. The rupture of the dam formed a wave of mud that overflowed riverbeds, and millions of tons of sediment were deposited on river terraces (Brito \& Matrodi Neto, 2016; Guerra et al., 2017; Lacaz et al., 2017).

According to Parra et al. (2007), the mining activity in the region of Quadrilátero Ferrífero has impacted the rivers by increasing the levels of suspended material and water turbidity. Furthermore, Rodrigues et al. (2015) determined that fine-grained sediments of less than $63 \mu \mathrm{m}$, which contribute the most to heavy-metal content, may act as possible sources of contamination. This is because these metals are not permanently fixed, and are available throughout the water column due to changes in environmental conditions, such as variations in $\mathrm{pH}$ and redox potential, or the presence of organic chelators. These characteristics negatively impact water quality, which requires additional treatment before distribution for human consumption. Concentration, exposure time, chemical composition, and sediment granulometry are pollutant factors that determine the degree of effects on aquatic organisms. For example, high levels of turbidity can damage the biota due to low levels of light entering the lotic environment, and may result in fish poisoning (Kemker, 2014). The fine particles are those that remain longer in suspension and have the highest dispersion capacity, which represents a long-term threat to the biota (Bilotta \& Brazier, 2008).

The dam accident has strongly affected riverine, freshwater, marine ecosystems (mainly at the mouth of

\footnotetext{
${ }^{1}$ Universidade Federal Rural do Rio de Janeiro (UFRRJ), Seropédica, RJ, Brasil

${ }^{2}$ Universidade Federal de Viçosa (UFV), Viçosa, MG, Brasil

${ }^{3}$ Universidade Federal do Espírito Santo (UFES), Vitória, ES, Brasil
} 
the Doce River), and ecological processes that support livelihoods, by disrupting fishing, agriculture, tourism, and water supply for the population residing in the Doce River Basin (Fernandes et al., 2016). This study aimed to evaluate the physiochemical characteristics of the water from the Gualaxo do Norte and Carmo Rivers, five to nine months after the dam rupture. This analysis was then compared to the results of previous studies conducted prior to the Fundão Dam breaking, and to the limits established in the Conama Resolution 357.

\section{MATERIALS AND METHODS}

\subsection{Study area}

The study area included sections of the Gualaxo do Norte and Carmo Rivers (Figure 1), in the city of Barra Longa, Minas Gerais, Brazil. The region climate is classified as subtropical highland $(\mathrm{CWb})$, with hot and rainy summers, dry winters, and an average annual rainfall of $1,552 \mathrm{~mm}$ (Oliveira \& Salgado, 1987).

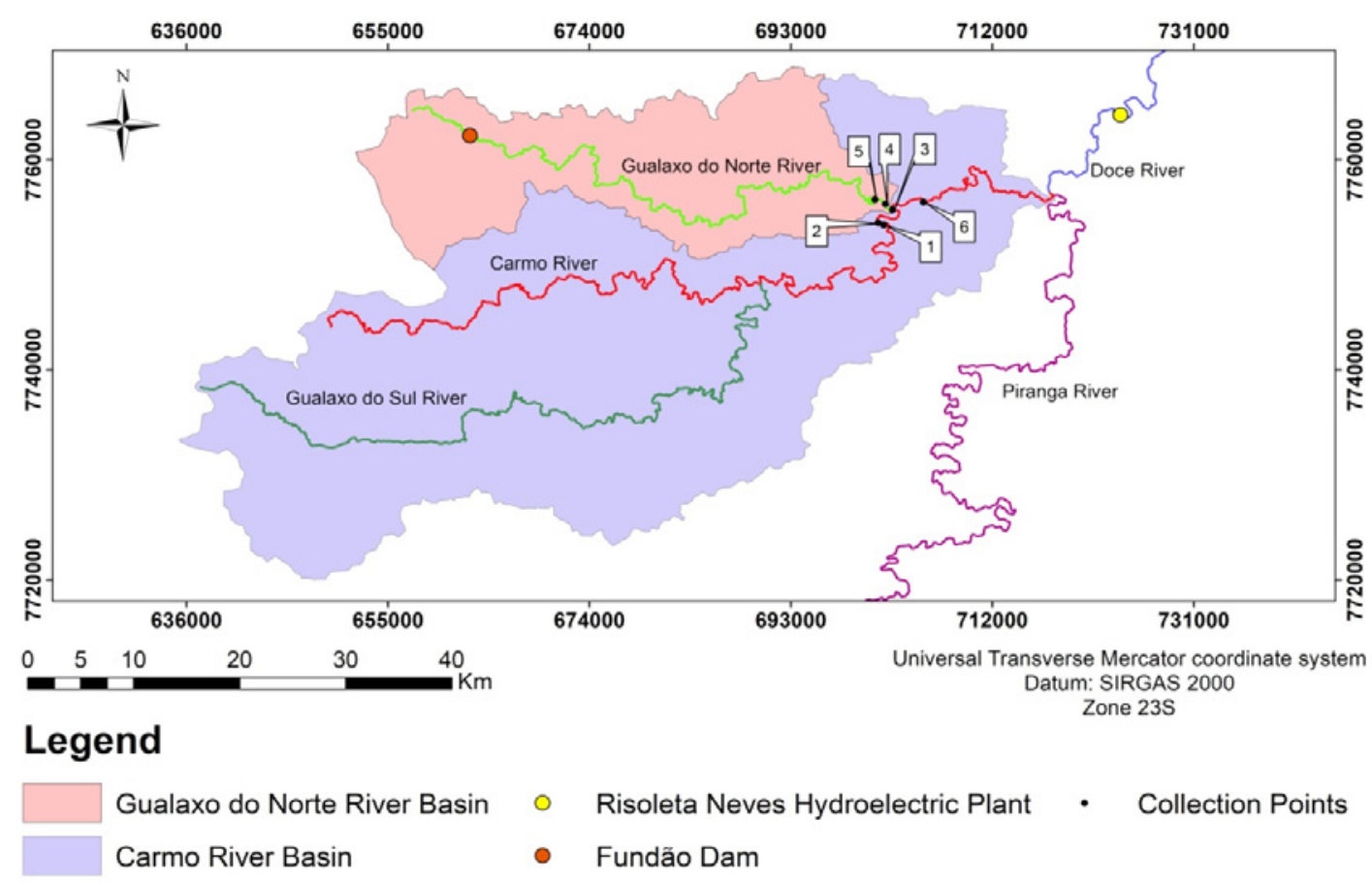

Figure 1. Location of the study area and sample points.

The Gualaxo do Norte River Basin's headwaters are located near the district of Antônio Pereira (Ouro Preto, MG) and Bento Rodrigues (Mariana, MG), at an altitude $\sim 1,300 \mathrm{~m}$ (Rodrigues et al., 2012). The Carmo River's main trainers, the Funil and Tripuí Streams that originate in the Serra do Veloso, are located near the headwaters in the municipality of Ouro Preto, MG. According to Campos (2014), the Carmo Riverbed has a history of ore exploration, and the Quadrilátero Ferrifero was the first region to begin gold mining in Brazil. The river extends for 134 $\mathrm{km}$ until its confluence with the Piranga River as they form the Doce River. Among its tributaries are the Gualaxo do Norte River on the left bank and the Gualaxo do Sul River on the right bank (Rodrigues et al., 2012). The sub-basins form the landscape of "Mares de Morros" (Ab'Saber, 2007), which is indicated by areas of relief characteristic of the original material associated with surface water dynamics. At the top of the Gualaxo do Norte and Carmo Rivers are rock outcrops of quartzite, itabirite, and phyllites, with soil classified by the WRB System as Ferralsols, Leptosols and Cambisols (Schaefer et al., 2017). Downstream, the riverbeds are formed out of eutrophic Ferralsols (Fernandes Filho et al., 2010). The phytophysiognomy that characterizes the region is a semi-decidual seasonal forest (Gonçalves et al., 2011).

With the rupture of the dam, the mud waves removed the topsoil along the fluvial terrace of the Gualaxo do Norte River. Then, the mining tailings were deposited in the gutter and banks (Schaefer et al., 2016). The deposition of the tailings drastically increased sediment concentrations and turbidity levels throughout the Doce River for several days. In certain stretches of the river, these levels surpassed 1,000 Nephelometric Turbidity Units (NTU), as was the case in the municipality of Mariana, which showed the highest value $(606,200$ NTU) for this parameter on November 7, 2015 (Minas Gerais, 2015a). 


\subsection{Data collection}

A total of thirty-six water samples were collected at six points on six days in 2016 (April 21, May 24, June 20, July 7, August 10, and September 12). These collection points were distributed so that three of them were located in the Carmo River (two before the mouth of the Gualaxo do Norte River and one after its disruption), and three in the Gualaxo do Norte River before it flows into the Carmo River.

The location of the collection points was selected in order to portray three different situations, in which: (1) the river was not contaminated by the mud from the accident, (2) the river was contaminated, and (3) the two rivers confluence. Points 1 and 2 were located in the Carmo River, before the drainage of the Gualaxo do Norte River; that is, before receiving the tailings resulting from the rupture of the Fundão Dam.

Samples were collected according to the Brazilian Norm NBR 9898 Standard developed by the Brazilian Association of Technical Standards (Cetesb, 2011). The instrument was dipped quickly into the water with the mouth down, and then turned in the opposite direction of the current. The sample was taken at a cross section of the river, fixed with an extender to provide distance between the collection point and the riverbank. Using the Hanna model multi-parameter HI 991300 ( 2 drops), we obtained the activity of hydrogen ions $(\mathrm{pH})$, activity of electrons (Eh), electrical conductivity (EC), dissolved solids (DS), and temperature. The samples were then cooled to $4{ }^{\circ} \mathrm{C}$ in a $500 \mathrm{~mL}$ clear bottle (Cetesb, 2011).

\subsection{Physicochemical analysis}

Turbidity was determined in the Water and Sewage Division of the Federal University of Viçosa (UFV) using the samples collected in transparent flasks, with a turbidimeter and a nephelometric method that involves comparison with standard solutions of known turbidity. Color was determined by colortest apparatus (Cetesb, 2011). Each sample of the amber flasks use $9 \mathrm{~mL}$ of collected water, which received $2 \mathrm{~mL}$ of $\mathrm{HNO}_{3}$ for microbead digestion and were separated using the microwave assisted acid digestion method of aqueous samples and extracts (United States, 2007). This process prepares the solution for analyzing its total heavy metal content $(\mathrm{Cr}, \mathrm{Cu}, \mathrm{Mn}, \mathrm{Ni}, \mathrm{Fe}, \mathrm{Cd}$, $\mathrm{Pb}$ ) in ICP OES (Inductively Coupled Plasma Optical Emission Spectrometry), according to Smichowski et al. (2005).

\section{RESULTS AND DISCUSSION}

The results showed high variability over time and were influenced mainly by the volume of rainfall that affected the flow and river water quality. According to Garcia \& Gonçalves (2011) and Thomaz et al. (2011), sediment transport is a natural process in fluvial channels, and water characteristics are constantly altered by erosive processes occurring on river slopes and banks. Therefore, an increase in solids loading would be expected when the flow intensifies, due to the volume of rainfall, floor material, and river slopes (Medeiros et al., 2011). Furthermore, sediments influence water quality parameters as they can carry other polluting elements with them throughout the waterways (Sutton \& Fisher, 2009; Meng et al., 2009). Therefore, in this study, precipitation directly influenced the water quality of the studied rivers because of the contribution of material from the accident, which was deposited on the riverbanks and consequently altered the turbidity and color of the water.

From April to September 2016, it rained approximately $224.5 \mathrm{~mm}$, which was higher than the average of $165.5 \mathrm{~mm}$ (Table 1) (Oliveira \& Salgado, 1987). This precipitation data generated a correlation of 0.44 between precipitation and turbidity, which may be a function of the distance between the meteorological station and the physiochemical data collection points in the water $(\sim 15 \mathrm{~km})$.

Table 1. Precipitation during the data collection period in the study region.

\begin{tabular}{lccc}
\multirow{2}{*}{ Month } & \multicolumn{3}{c}{ Precipitation $(\mathbf{m m})$} \\
\cline { 2 - 4 } April & $\mathbf{1 0}$ days $^{*}$ & $\mathbf{2 0 1 6 ^ { * * }}$ & Normal $^{* * *}$ \\
\hline May & 0.3 & 43.4 & 55.8 \\
\hline June & 2.8 & 3.3 & 28.8 \\
\hline July & 4.4 & 74.4 & 11.5 \\
\hline August & 0.3 & 0.3 & 15.3 \\
September & 0 & 9.2 & 14.8 \\
\hline Total & 2.3 & 93.9 & 39.3 \\
\hline
\end{tabular}

* Rain accumulated 10 days before collection. ${ }^{*}$ Data from the automatic meteorological station located in the municipality of Acaiaca, MG. $* * *$ Normal climatological data from 1961-1990. Source: National Institute of Meteorology, 2016.

Many authors have evaluated the effects of precipitation on turbidity behavior in river water (Silva et al., 2009). For example, Oliveira \& Cunha (2014) studied the correlation between precipitation and turbidity in the rivers in southern Amapá and determined a correlation value of 0.87 . In our study, as shown in Table 2 and Figures 2 and 3, the highest turbidity levels occurred at Points 3, 4, and 5, which were located in the Gualaxo do Norte River. This is the result of the largest waste deposit, between 145 and 635 NTU, and the contribution of rainfall to the coefficient of variation. 
Table 2. Statistical summary of the analytical results.

\begin{tabular}{|c|c|c|c|c|c|c|c|c|c|c|c|c|c|c|}
\hline \multirow[t]{2}{*}{ Point } & Temperature & pH & Eh & EC & DS & Turbidity & $\begin{array}{l}\text { Water } \\
\text { color }\end{array}$ & $\mathrm{Cr}$ & $\mathrm{Cu}$ & Mn & $\mathrm{Fe}$ & $\mathbf{N i}$ & Cd & $\mathbf{P b}$ \\
\hline & ${ }^{\circ} \mathrm{C}$ & & & $\mu \mathrm{S} / \mathrm{cm}$ & $\mathrm{mg} / \mathrm{L}$ & NTU & $\mathrm{mg} \mathrm{Pt} / \mathrm{L}$ & \multicolumn{7}{|c|}{$\mathrm{mg} / \mathrm{L}$} \\
\hline \multicolumn{15}{|l|}{ Mean } \\
\hline 1 & 21.3 & 6.2 & 172.0 & 0.100 & 0.042 & 7.5 & 22.5 & 0.002 & 0.010 & 0.059 & 0.127 & 0.004 & 0.003 & 0.040 \\
\hline 2 & 21.6 & 6.2 & 191.3 & 0.085 & 0.040 & 7.0 & 22.2 & 0.005 & 0.010 & 0.051 & 0.138 & 0.008 & 0.005 & 0.043 \\
\hline 3 & 22.2 & 6.1 & 198.0 & 0.080 & 0.042 & 360.2 & 370.2 & 0.007 & 0.021 & 0.262 & 2.595 & 0.009 & 0.005 & 0.040 \\
\hline 4 & 22.0 & 6.1 & 215.3 & 0.075 & 0.038 & 316.3 & 341.7 & 0.003 & 0.024 & 0.250 & 3.253 & 0.008 & 0.005 & 0.041 \\
\hline 5 & 21.8 & 6.1 & 230.8 & 0.075 & 0.038 & 328.7 & 344.3 & 0.004 & 0.022 & 0.260 & 3.140 & 0.014 & 0.007 & 0.033 \\
\hline 6 & 23.0 & 6.1 & 225.5 & 0.088 & 0.043 & 88.8 & 96.4 & 0.004 & 0.020 & 0.091 & 0.481 & 0.010 & 0.005 & 0.040 \\
\hline \multicolumn{15}{|c|}{ Standard deviation } \\
\hline 1 & 2.68 & 1.01 & 54.35 & 0.04 & 0.01 & 4.38 & 10.63 & 0.004 & 0.002 & 0.031 & 0.095 & 0.006 & 0.003 & 0.010 \\
\hline 2 & 2.64 & 0.91 & 53.26 & 0.02 & 0.01 & 3.55 & 9.82 & 0.007 & 0.001 & 0.029 & 0.144 & 0.007 & 0.003 & 0.015 \\
\hline 3 & 2.86 & 0.84 & 42.92 & 0.01 & 0 & 150.49 & 163.19 & 0.008 & 0.005 & 0.130 & 1.436 & 0.010 & 0.004 & 0.013 \\
\hline 4 & 3.41 & 0.82 & 62.63 & 0.01 & 0 & 184.61 & 230.12 & 0.005 & 0.007 & 0.156 & 2.254 & 0.008 & 0.003 & 0.012 \\
\hline 5 & 2.60 & 0.87 & 68.76 & 0.01 & 0 & 142.47 & 158.74 & 0.004 & 0.005 & 0.141 & 3.216 & 0.007 & 0.002 & 0.014 \\
\hline 6 & 2.00 & 0.90 & 74.01 & 0.03 & 0.01 & 46.32 & 44.92 & 0.003 & 0.005 & 0.045 & 0.284 & 0.011 & 0.004 & 0.007 \\
\hline \multicolumn{15}{|c|}{ Coefficient of variation } \\
\hline 1 & 0.13 & 0.16 & 0.32 & 0.42 & 0.28 & 0.59 & 0.47 & 1.69 & 0.21 & 0.53 & 0.75 & 1.39 & 0.99 & 0.25 \\
\hline 2 & 0.12 & 0.15 & 0.28 & 0.23 & 0.16 & 0.51 & 0.44 & 1.59 & 0.11 & 0.57 & 1.05 & 0.94 & 0.69 & 0.35 \\
\hline 3 & 0.13 & 0.14 & 0.22 & 0.16 & 0.10 & 0.42 & 0.44 & 1.11 & 0.24 & 0.50 & 0.55 & 1.11 & 0.77 & 0.32 \\
\hline 4 & 0.15 & 0.13 & 0.29 & 0.07 & 0.11 & 0.58 & 0.67 & 1.81 & 0.29 & 0.62 & 0.69 & 0.97 & 0.65 & 0.30 \\
\hline 5 & 0.12 & 0.14 & 0.30 & 0.11 & 0.11 & 0.43 & 0.46 & 1.07 & 0.21 & 0.54 & 1.02 & 0.50 & 0.35 & 0.43 \\
\hline 6 & 0.09 & 0.15 & 0.33 & 0.29 & 0.32 & 0.52 & 0.47 & 0.77 & 0.25 & 0.49 & 0.59 & 1.08 & 0.82 & 0.17 \\
\hline \multicolumn{15}{|c|}{ Maximum values } \\
\hline 1 & 24.5 & 7.4 & 248.0 & 0.2 & 0.1 & 15.1 & 36.5 & 0.010 & 0.012 & 0.113 & 0.240 & 0.013 & 0.007 & 0.050 \\
\hline 2 & 25.0 & 6.9 & 273.0 & 0.1 & 0.1 & 13.4 & 34.0 & 0.016 & 0.012 & 0.091 & 0.372 & 0.019 & 0.010 & 0.066 \\
\hline 3 & 26.0 & 6.9 & 247.0 & 0.1 & 0.1 & 580.0 & 628.0 & 0.018 & 0.025 & 0.441 & 4.683 & 0.026 & 0.010 & 0.050 \\
\hline 4 & 27.0 & 7.0 & 300.0 & 0.1 & 0 & 635.0 & 773.0 & 0.013 & 0.033 & 0.464 & 7.234 & 0.020 & 0.009 & 0.056 \\
\hline 5 & 26.0 & 7.1 & 306.0 & 0.1 & 0 & 550.0 & 618.0 & 0.009 & 0.026 & 0.435 & 9.126 & 0.023 & 0.009 & 0.055 \\
\hline 6 & 25.0 & 7.1 & 320.0 & 0.1 & 0.1 & 168.0 & 175.0 & 0.008 & 0.026 & 0.166 & 0.752 & 0.023 & 0.010 & 0.047 \\
\hline \multicolumn{15}{|c|}{ Minimum values } \\
\hline 1 & 18.0 & 4.5 & 111.0 & 0.1 & 0 & 2.4 & 9.5 & 0 & 0.006 & 0.025 & 0 & 0 & 0 & 0.024 \\
\hline 2 & 18.0 & 4.6 & 132.0 & 0.1 & 0 & 2.8 & 9.5 & 0 & 0.009 & 0.025 & 0 & 0 & 0.001 & 0.030 \\
\hline 3 & 18.0 & 4.7 & 150.0 & 0.1 & 0 & 171.0 & 172.0 & 0 & 0.011 & 0.104 & 0.606 & 0 & 0.001 & 0.020 \\
\hline 4 & 18.0 & 4.9 & 154.0 & 0.1 & 0 & 145.0 & 139.0 & 0 & 0.012 & 0.111 & 1.325 & 0 & 0.001 & 0.022 \\
\hline 5 & 18.5 & 4.8 & 150.0 & 0.1 & 0 & 155.0 & 168.0 & 0 & 0.013 & 0.104 & 0 & 0.006 & 0.003 & 0.011 \\
\hline 6 & 20.0 & 4.7 & 149.0 & 0.1 & 0 & 35.0 & 55.0 & 0 & 0.011 & 0.033 & 0.067 & 0 & 0.001 & 0.031 \\
\hline
\end{tabular}

pH: activity of hydrogen ions; Eh: activity of electrons; EC: electrical conductivity; DS: dissolved solids; NTU: nephelometric turbidity units.

The results in Table 2 show that turbidity levels stabilized within the study period, as the affected areas of the Gualaxo do Norte River had the same coefficient of variation as the control area in the Carmo River, before its confluence with the Gualaxo do Norte River (Points 1 and 2), where the tailings were not present. However, Figure 2 illustrates the strong influence of precipitation on variations in turbidity, which was more intense in April, at the end of the rainy season. In
July, a small increase occurred due to a concentrated rainy event that happened at the end of the previous month. This phenomenon was also observed in September.

The samples taken from the Carmo River (Points 1 and 2) had low turbidity values that changed immediately after the confluence with the Gualaxo do Norte River, and rose to an average value close to the limit for Class 2 water $(\leq 100 \mathrm{NTU})$ recommended in the Conama Resolution 357. 


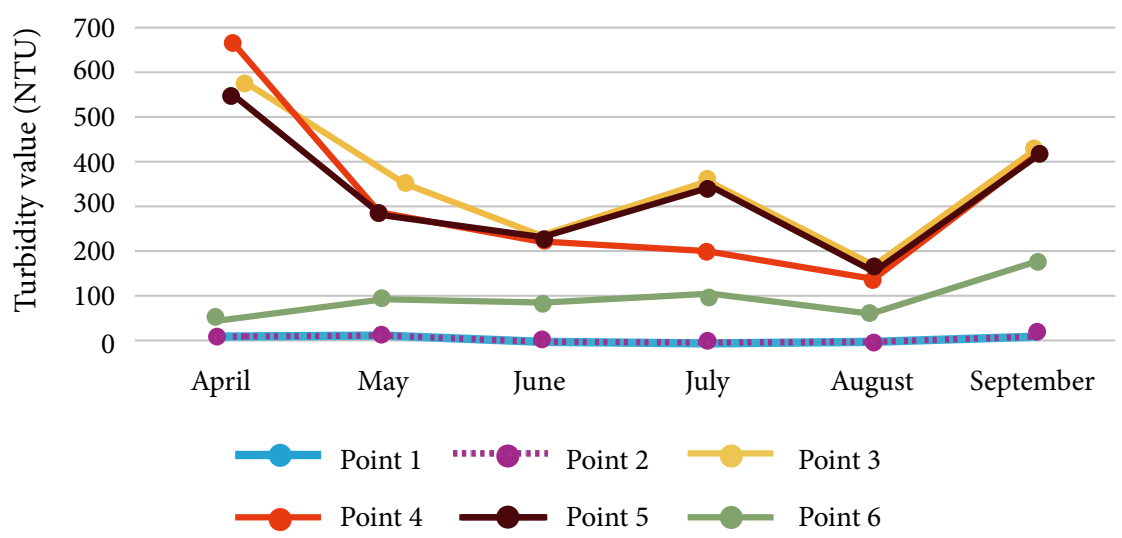

Figure 2. Dynamics of water turbidity at different points in the studied period.

The turbidity values observed by the Mining Institute of Water Management (Minas Gerais, 2015a) for the period after the dam disruption, in a location close to that of this study, was 35,200 NTU. However, the author emphasized that, over time, and depending on the tendency of solids to precipitate at the bottom of the river, turbidity levels would decline and approach the standard values for Class 2 water ( $\leq 100 \mathrm{NTU})$. Nevertheless, the rain, and consequent increase in flow rate and speed of the water, stirred previously deposited material and resulted in an increased turbidity. This study determined that, before the confluence of the rivers, the values showed averages three times greater than the allowable limit, and, in the dry period, the minimum value did not go below 100 NTU. However, shortly after the confluence with the Carmo
River at Point 6, the average turbidity decreased to 88 NTU and resulted in a Class 2 water classification. This is due to the improved water quality of the Carmo River (Points 1 and 2) that assisted in the dilution of materials coming from the Gualaxo do Norte River (Points 3, 4 and 5), which, together, flowed to the Carmo River (Point 6) towards the city of Barra Longa.

Certain parameters of water quality displayed high correlations between them, indicating that they are subject to the same variations. This is demonstrated in Figures 3 and 4 , where color and iron content showed similar patterns corresponding to turbidity. This results from the type of tailings deposited in these waters with high iron content, and which, according to Azevedo (2006), contributed to an increased water color and turbidity.

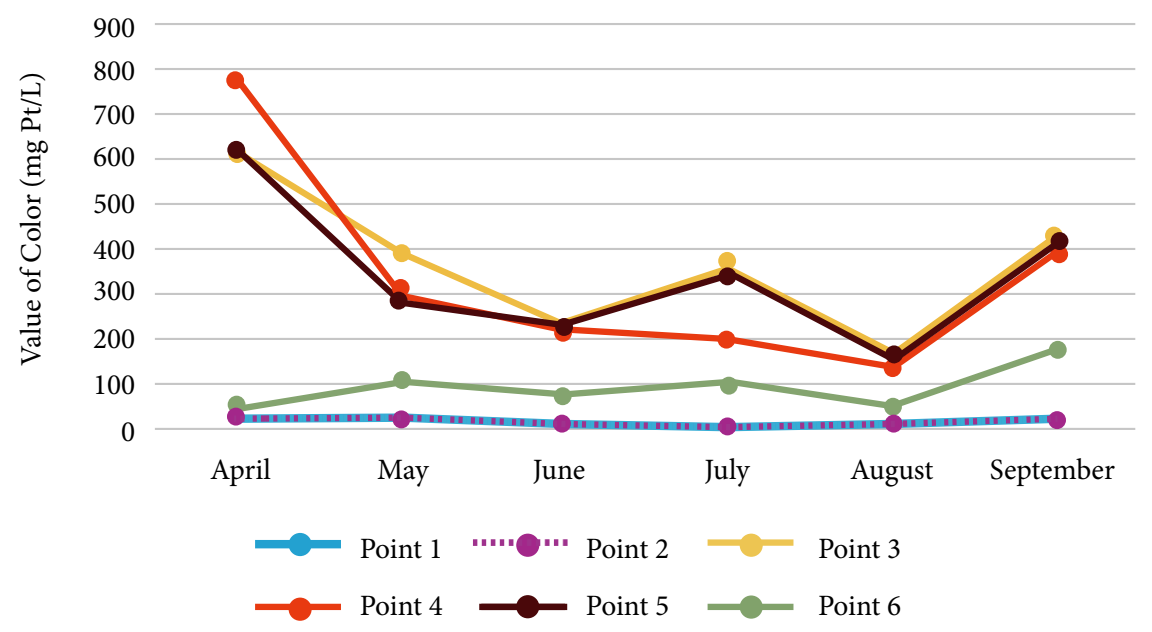

Figure 3. Dynamics of water color at the collection points during the study period. 
As indicated in Table 2, waste disposal did not alter the $\mathrm{pH}$ value of the water, as comparable values were noted between the affected and unaffected areas. Similar behavior was shown for electrical conductivity, except for Point $1(0.10 \mu \mathrm{S} / \mathrm{cm})$. This datum confirms the observations made by the Brazilian Institute of Environment and Renewable Natural Resources (Ibama, 2015) that addressed the tailings as inert material with the potential to cause chemical disruption, in accordance with the NBR 10.004 Standard.

As shown in Table 3, high correlations were observed between heavy metals, particularly $\mathrm{Mn}$ and $\mathrm{Cu}$, and physiochemical attributes. The first is often found associated with $\mathrm{Fe}$, and, in a study by Carvalho \& Oliveira (2010), Mn was similar to Fe, both geochemically and in its occurrence in natural waters. However, as indicated in this study, the presence of $\mathrm{Mn}$ in water was less common than that of $\mathrm{Fe}$, and its concentration was also lower, with a mean of $0.16 \mathrm{mg} / \mathrm{L}$.

Table 3. Correlation between the elements and turbidity, color and iron.

\begin{tabular}{lccc}
\hline Correlated variables & Turbidity & Color & Fe \\
\hline Temperature & 0.21 & 0.19 & 0.09 \\
\hline $\mathrm{pH}$ & -0.73 & -0.72 & -0.67 \\
$\mathrm{Eh}$ & 0.54 & 0.53 & 0.56 \\
\hline Electric conductivity & -0.83 & -0.83 & -0.86 \\
\hline Dissolved solids & -0.46 & -0.49 & -0.64 \\
\hline Turbidity & 1 & 0.99 & 0.97 \\
\hline $\mathrm{Color}$ & 0.99 & 1 & 0.98 \\
$\mathrm{Fe}$ & 0.97 & 0.98 & 1 \\
$\mathrm{Cr}$ & 0.35 & 0.32 & 0.14 \\
$\mathrm{Cu}$ & 0.88 & 0.88 & 0.86 \\
$\mathrm{Mn}$ & 0.99 & 0.99 & 0.98 \\
$\mathrm{Ni}$ & 0.59 & 0.58 & 0.58 \\
$\mathrm{Cd}$ & 0.68 & 0.68 & 0.71 \\
$\mathrm{~Pb}$ & -0.50 & -0.49 & -0.52 \\
\hline
\end{tabular}

Eh: activity of electrons.
Elements including $\mathrm{Mn}, \mathrm{Cu}, \mathrm{Cd}$, and $\mathrm{Ni}$ bind to iron oxides (Barbosa et al., 2005) that influences the distribution of these materials. Consequently, color and turbidity parameters would be highly correlated, since these are altered by Fe concentration. According to Silva et al. (2009), turbidity values change according to the dissolved elements in water, especially Fe.

The iron content in the Gualaxo do Norte Riverbed showed a maximum value of $9 \mathrm{mg} / \mathrm{L}$ at Point 5 in April and was absent at Points 1 and 2 in July. Barbosa et al. (2005) found large quantities of $\mathrm{Fe}$ in the main bed of the Gualaxo do Norte River (Point 5 in the month of April) and total absence in Points 1 and 2, in July. Barbosa et al. (2005) found large amounts of $\mathrm{Fe}$ in the main bed of the Gualaxo do Norte River in 2015 (before the accident), much larger than in its tributaries, which may indicate that this element and the others shown do not come from local geology, but from leaks from iron ore tailings deposits at the head of the river.

Another situation that arose after the breaking of the Fundão Dam was the structural instability of the tailings that were transported by rainwater and deposited on the terraces of the Gualaxo do Norte and Carmo Rivers. This process was difficult to control and to determine the amount of tailings transported from the terrace to the river channel, since the degree of intensity was directly related to the volume of precipitation and the type of interventions that the company responsible for recovery had implemented in those areas.

The publication by Minas Gerais (2015b) classified the Carmo River water as Class 2 in the Conama Resolution 357, based on data from the historical series of points distributed along its gutter, and turbidity levels from 9-83 NTU. In this study, turbidity, color, and mean iron content levels of the Carmo River samples collected at the points without contamination were 2.4-15.1 NTU, 9.5-36.5 mg Pt/L, and 0.14 mg/L, respectively. These data confirmed that the samples were within the standard for Class 2 water in the Conama Resolution 357.

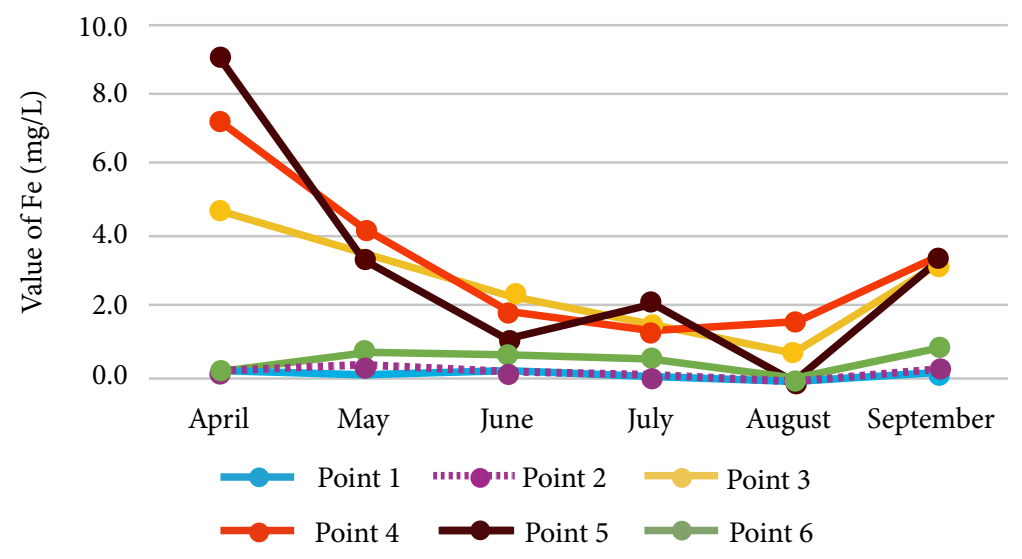

Figure 4. Dissolved Iron Dynamics (Method US - EPA 3015A). 
The large quantity of tailings deposited on the banks and at the bottom of the rivers altered the content of the elements in the Gualaxo do Norte River for turbidity and color, except for $\mathrm{Mn}$ and $\mathrm{Fe}$ that showed levels 5 and 25 times higher than in the Carmo River, respectively. As shown in Table 4, $\mathrm{Cr}, \mathrm{Cd}$, and $\mathrm{Pb}$ values were higher than the allowed limit for Class 2 water in the Conama Resolution 357.

In observing the results of the Carmo River, downstream from the mouth of the Gualaxo do Norte River, turbidity values and concentrations of $\mathrm{Cr}, \mathrm{Mn}, \mathrm{Fe}, \mathrm{Cd}$, and $\mathrm{Pb}$ decreased. In general, the water contaminated by the discharges from the Fundão Dam demonstrated values well above the recommended classification of rivers for Class 2 water in the
Conama Resolution 357. Values were also observed above those established for Class 3 freshwater in the Conama Resolution 357, which is intended for human consumption after conventional or advanced treatment, with turbidity and color limits of $100 \mathrm{NTU}$ and $75 \mathrm{mg} \mathrm{Pt} / \mathrm{L}$, respectively. Contaminated riverbed water had a turbidity level of 635 NTU and color of $776 \mathrm{Pt} / \mathrm{L}$, which prevented it from being abstracted, treated, and distributed for human consumption. Table 5 compares these results with the values established by the Conama Resolution 357. This is due to the extreme turbidity levels showed during the rainy periods. In addition, the sanitation concessionaire water treatment plants do not perform the advanced treatment required for Class 3 freshwater in the Conama Resolution 357.

Table 4. Comparison of the physiochemical attributes of the Gualaxo do Norte River water, with pattern values from the Conama Resolution 357.

\begin{tabular}{|c|c|c|c|c|c|c|c|}
\hline \multirow{2}{*}{ Physiochemical characteristics } & \multirow{2}{*}{$\begin{array}{c}\text { "Class 2" } \\
\text { Conama } 357\end{array}$} & \multicolumn{6}{|c|}{ Gualaxo do Norte River/2016 } \\
\hline & & $21 / 04$ & $24 / 05$ & $20 / 06$ & 07/07 & $10 / 08$ & $12 / 09$ \\
\hline Water temp. on-the-spot ${ }^{\circ} \mathrm{C}$ & Unlimited patterns & 26.33 & 24.00 & 18.17 & 21.33 & 21.33 & 22.00 \\
\hline $\mathrm{pH}$ on-the-spot & 6.0 to 9.0 & 6.50 & 6.90 & 4.80 & 5.87 & 5.87 & 7.00 \\
\hline Eh on-the-spot & Unlimited patterns & 243.3 & 273.0 & 274.3 & 183.0 & 183.0 & 161.0 \\
\hline Conductivity $(\mathrm{mS} / \mathrm{cm})$ on-the-spot & Unlimited patterns & 0.08 & 0.07 & 0.07 & 0.09 & 0.09 & 0.07 \\
\hline Dissolved solids (mg/L) on-the-spot & 500 & 400 & 370 & 400 & 400 & 400 & 400 \\
\hline Turbidity (NTU) & 100 & 588.3 & 304.3 & 225.6 & 296.6 & 296.6 & 438.3 \\
\hline Color (mg Pt/L) & 75 & 673.0 & 336.6 & 222.3 & 306.6 & 306.6 & 414.0 \\
\hline $\mathrm{Cr}(\mathrm{mg} / \mathrm{L})$ & 0.05 & 0 & 0 & 0 & 0.01 & 0.01 & 0.01 \\
\hline $\mathrm{Cu}(\mathrm{mg} / \mathrm{L})$ & 0.09 & 0.03 & 0.02 & 0.02 & 0.02 & 0.02 & 0.03 \\
\hline $\mathrm{Mn}(\mathrm{mg} / \mathrm{L})$ & 0.10 & 0.43 & 0.22 & 0.14 & 0.22 & 0.22 & 0.43 \\
\hline $\mathrm{Fe}(\mathrm{mg} / \mathrm{L})$ & 0.30 & 7.01 & 3.62 & 1.71 & 1.62 & 1.62 & 3.29 \\
\hline $\mathrm{Ni}(\mathrm{mg} / \mathrm{L})$ & 0.025 & 0.003 & 0.004 & 0.011 & 0.009 & 0.009 & 0.021 \\
\hline $\mathrm{Cd}(\mathrm{mg} / \mathrm{L})$ & 0.001 & 0.002 & 0.004 & 0.005 & 0.006 & 0.006 & 0.009 \\
\hline $\mathrm{Pb}(\mathrm{mg} / \mathrm{L})$ & 0.01 & 0.02 & 0.03 & 0.04 & 0.04 & 0.04 & 0.05 \\
\hline
\end{tabular}

Eh: activity of electrons.

Source: Mendes et al. (2016).

Table 5. Comparison of the results for the Carmo River, downstream of Gualaxo do Norte River, with pattern values from the Conama Resolution 357.

\begin{tabular}{|c|c|c|c|c|c|c|c|}
\hline \multirow{2}{*}{ Physiochemical characteristics } & \multirow{2}{*}{$\begin{array}{c}\text { “Class 2" } \\
\text { Conama } 357\end{array}$} & \multicolumn{6}{|c|}{ Carmo River downstream } \\
\hline & & $21 / 04$ & $24 / 05$ & $20 / 06$ & 07/07 & $10 / 08$ & $12 / 09$ \\
\hline Water temp. ${ }^{\circ} \mathrm{C}$ on-the-spot & Unlimited patterns & 25 & 24 & 20 & 24 & 21 & 24 \\
\hline $\mathrm{pH}$ on-the-spot & 6.0 to 9.0 & 6.8 & 6.7 & 4.7 & 5.9 & 5.6 & 7.1 \\
\hline Eh on-the-spot & Unlimited patterns & 255 & 294 & 320 & 180 & 149 & 155 \\
\hline Conductivity $(\mathrm{mS} / \mathrm{cm})$ on-the-spot & Unlimited patterns & 0.08 & 0.07 & 0.08 & 0.14 & 0.08 & 0.08 \\
\hline Dissolved solids (mg/L) on-the-spot & 500 & 400 & 400 & 400 & 400 & 400 & 400 \\
\hline Turbidity (NTU) & 100 & 35 & 87 & 88 & 103 & 52 & 168 \\
\hline Color (mg Pt/L) & 75 & 56 & 109 & 78 & 105 & 55 & 175 \\
\hline $\mathrm{Cr}(\mathrm{mg} / \mathrm{L})$ & 0.05 & 0 & 0.005 & 0.004 & 0.001 & 0.008 & 0.007 \\
\hline $\mathrm{Cu}(\mathrm{mg} / \mathrm{L})$ & 0.09 & 0.020 & 0.026 & 0.020 & 0.020 & 0.011 & 0.023 \\
\hline $\mathrm{Mn}(\mathrm{mg} / \mathrm{L})$ & 0.10 & 0.03 & 0.10 & 0.09 & 0.10 & 0.06 & 0.17 \\
\hline $\mathrm{Fe}(\mathrm{mg} / \mathrm{L})$ & 0.30 & 0.21 & 0.73 & 0.63 & 0.50 & 0.07 & 0.75 \\
\hline $\mathrm{Ni}(\mathrm{mg} / \mathrm{L})$ & 0.025 & 0 & 0.018 & 0 & 0.001 & 0.017 & 0.023 \\
\hline $\mathrm{Cd}(\mathrm{mg} / \mathrm{L})$ & 0.001 & 0.001 & 0.008 & 0.001 & 0.002 & 0.007 & 0.010 \\
\hline $\mathrm{Pb}(\mathrm{mg} / \mathrm{L})$ & 0.01 & 0.04 & 0.04 & 0.05 & 0.04 & 0.03 & 0.05 \\
\hline
\end{tabular}

Eh: activity of electrons.

Source: Mendes et al. (2016). 
At Point 6, where the water from the two rivers mix, Fe levels did not meet the standards for Class 2 water in the Conama Resolution 357. There was also a small increase in $\mathrm{Pb}$, the only element that falls outside the standards for Class 2 water. However, this higher content may be related to the natural presence of $\mathrm{Pb}$ at approximately $15 \mathrm{mg} /$ $\mathrm{kg}$ in the natural soils of this region, as was observed by Kabata-Pendias \& Pendias (2011), and confirmed by the relatively high $\mathrm{Pb}$ concentrations in the upstream water of the Carmo River, which was free from tailing contamination.

Table 6 compares the results of the upstream Carmo River and the values recognized by the Conama Resolution 357.

The values for turbidity and color of the Carmo River samples, collected before the mouth of the Gualaxo do Norte River, were 2.4-15.1 NTU and 9.5-36.5 mg Pt/L, respectively, and therefore, below the maximum allowed limit for Class 2 water. This location may be an alternative for collecting water that is safe for human consumption for the population upstream of its discharges. Unfortunately, there is not sufficient research on the presence of the other elements in these waters. In this study, the Conama 357 Resolution standard for Class 2 water is referenced regarding the distribution and use of water for human consumption. This is the system employed by sanitation concessionaires and it requires conventional water treatment including clarification with coagulation and flocculation, followed by disinfection and $\mathrm{pH}$ correction. Alternatively, Class 3 freshwater in the Conama Resolution 357, only allows advanced treatment techniques including the removal and/or inactivation of constituents, as well as refractory to conventional treatment processes, which may consist of water characteristics such as color, odor, taste, toxicity, or pathogenic activity (Mendes et al., 2016).

The Conama Resolution 357 (Brasil, 2005) limits the number of potential contaminants in the environment and stipulates in its Article 7, Paragraph 4, that "possible interactions between substances, the presence of unlisted contaminants liable to cause harm to living organisms shall be investigated using ecotoxicological, toxicological or other scientifically recognized methods." It also states that the public authority may, at any time, add other conditions and quality standards for a particular body of water, or make them more restrictive, considering local conditions through technical reasons (Mendes et al., 2016).

As stated by Magalhães \& Ferrão Filho (2008), ecotoxicity tests may be used to demonstrate the probability of toxic sources of pollution affecting the biota within a body of receiving water. This is based on the assumption that, if the agent was toxic to one or more species in a test system, it would likely be toxic to important ecosystem components, and, therefore, could cause negative environmental impacts. These authors also concluded that toxicological tests may be used as a tool for the continuous monitoring of water conditions in order to determine environmental impacts resulting from the implantation of productive enterprises. This information can be used to scientifically prove the environmental changes caused by criminal actions, or to justify the release of non-harmful chemicals.

Table 6. Comparison of results for the upstream Carmo River, with pattern values from the Conama Resolution 357.

\begin{tabular}{|c|c|c|c|c|c|c|c|}
\hline \multirow{2}{*}{ Physiochemical characteristics } & \multirow{2}{*}{$\begin{array}{c}\text { “Class 2" } \\
\text { Conama } 357\end{array}$} & \multicolumn{6}{|c|}{ Carmo River amount } \\
\hline & & $21 / 04$ & $24 / 05$ & $20 / 06$ & 07/07 & $10 / 08$ & $12 / 09$ \\
\hline Water temp. ${ }^{\circ} \mathrm{C}$ on-the-spot & Unlimited patterns & 24.7 & 23.7 & 18 & 19.5 & 20 & 22.5 \\
\hline $\mathrm{pH}$ on-the-spot & 6.0 to 9.0 & 6.55 & 7.15 & 4.55 & 5.6 & 6.45 & 6.80 \\
\hline Eh on-the-spot & Unlimited patterns & 168 & 228 & 235 & 202 & 132 & 124 \\
\hline Conductivity $(\mathrm{mS} / \mathrm{cm})$ on-the-spot & Unlimited patterns & 0.12 & 0.08 & 0.05 & 0.13 & 0.08 & 0.09 \\
\hline Dissolved solids (mg/L) on-the-spot & 500 & 350 & 350 & 350 & 350 & 450 & 400 \\
\hline Turbidity (NTU) & 100 & 7 & 6 & 8 & 3 & 5 & 14 \\
\hline Color (mg Pt/L) & 75 & 35 & 32 & 17 & 10 & 15 & 25 \\
\hline $\mathrm{Cr}(\mathrm{mg} / \mathrm{L})$ & 0.05 & 0 & 0 & 0 & 0 & 0.01 & 0.01 \\
\hline $\mathrm{Cu}(\mathrm{mg} / \mathrm{L})$ & 0.09 & 0.01 & 0.01 & 0.01 & 0.01 & 0.01 & 0.01 \\
\hline $\mathrm{Mn}(\mathrm{mg} / \mathrm{L})$ & 0.10 & 0.03 & 0.08 & 0.04 & 0.03 & 0.05 & 0.10 \\
\hline $\mathrm{Fe}(\mathrm{mg} / \mathrm{L})$ & 0.30 & 0.06 & 0.26 & 0.19 & 0 & 0.05 & 0.24 \\
\hline $\mathrm{Ni}(\mathrm{mg} / \mathrm{L})$ & 0.025 & 0.005 & 0 & 0 & 0.010 & 0.010 & 0.010 \\
\hline $\mathrm{Cd}(\mathrm{mg} / \mathrm{L})$ & 0.001 & 0.002 & 0.001 & 0.001 & 0.005 & 0.006 & 0.010 \\
\hline $\mathrm{Pb}(\mathrm{mg} / \mathrm{L})$ & 0.01 & 0.04 & 0.03 & 0.04 & 0.05 & 0.04 & 0.03 \\
\hline
\end{tabular}

Eh: activity of electrons.

Source: Mendes et al. (2016). 


\section{CONCLUSIONS}

In general, the physicochemical characteristics of river water increased significantly with the collapse of the Fundão Dam; however, during this study period, a reduced turbidity levels and iron and color content was observed. This trend was interrupted during rainy periods due to revolving and transported material from the riverbanks to the riverbeds. Turbidity and color levels were directly related to dissolved iron content, and the elements chromium, copper, nickel, cadmium, and manganese were strongly correlated with iron.

The Carmo River had turbidity, color, and iron levels within the limits for Class 2 water. These characteristics assisted in the dilution of the pollutants coming from the Gualaxo do Norte River after its outfall; therefore, this location might be an alternative site for capturing and treating water for human consumption.

During periods of pluviometric peaks, the Gualaxo do Norte River had contamination values above those established for Class 3 freshwater in the Conama Resolution 357, which is the standard applied to water for human consumption after advanced treatment. As demonstrated in this study, by monitoring the physiochemical characteristics of river water, abstraction, treatment, and distribution of water for human consumption might be suspended until conditions improve. To better understand the presence of contaminants not mentioned in the Conama Resolution 357, further indepth and specific toxicity studies are recommended. This research can contribute to the development and proposal of regulations, as well as the creation of a special water quality classification system that is dependent on the characteristics of the water.

\section{ACKNOWLEDGEMENTS}

I thank the Graduate Program in Environmental and Forestry Sciences, Universidade Federal Rural do Rio de Janeiro, since this article is part of the research developed during my master's degree in this program. I am also grateful for the support of the Coordenação de Aperfeiçoamento de Pessoal de Nível Superior (Capes), which provided the scholarship. Thank you to the Universidade Federal de Viçosa, colleagues, teachers and employees of the Water Treatment Station, the Department of Soils and especially the Labgeo.

\section{SUBMISSION STATUS}

Received: 23 Mar. 2018

Accepted: 13 Sept. 2018

Associate editor: Rodrigo Studart Corrêa

(D) 0000-0002-9422-2629

\section{CORRESPONDENCE TO}

\section{Meri Diana Strauss Foesch}

Estrada Linha Principal, 1.180, Bairro Rural, CEP 98640-000, Crissiumal, RS, Brasil

e-mail: meridiana.sf@gmail.com

\section{REFERENCES}

Ab'Saber AN. Os domínios de natureza no Brasil: potencialidades paisagísticas. 4th ed. São Paulo: Ateliê; 2007.

Azevedo RP. Uso da água subterrânea em sistema de abastecimento público de comunidade de várzeas na Amazônia Central. Acta Amazônica 2006; 36(4):313-320. 10.1590/S0044-59672006000300004

Barbosa SES, Barbosa AR Jr, Silva GQ, Campos ENB, Rodrigues VC. Geração de modelos de regionalização de vazões máximas, médias de longo período e mínimas de sete dias para a Bacia do Rio do Carmo, Minas Gerais. Engenharia Sanitária e Ambiental 2005; 10(1): 64-71. 10.1590/S1413-41522005000100008

Brasil. Conselho Nacional do Meio Ambiente - Conama. Resolução Conama n. 357, de 17 de março de 2005. Diário Oficial da República Federativa do Brasil, Brasília, DF (2005 Mar. 18); Sec. 1: 58-63.

Brito BDC, Mastrodi Neto J. As esferas de responsabilidade pelo dano ambiental: aplicação ao caso Samarco. Desenvolvimento e Meio Ambiente 2016; 39: 43-57. 10.5380/dma.v39i0.47182

Bilotta GS, Brazier RE. Understanding the influence of suspended solids on water quality and aquatic biota. Water Research 2008; 42(12): 2849-2861. 10.1016/j.watres.2008.03.018

Campos KMN. Vestígios da mineração de ouro na Serra do Veloso: uma contribuição à geo-história de Ouro Preto-MG. Revista Espinhaço 2014; 3(2): 15-27.

Carvalho AR, Oliveira MVC. Princípios básicos de saneamento do meio. 10th ed. São Paulo: Senac; 2010. 400p.

Cetesb. Guia nacional de coleta e preservação de amostras: água, sedimento, comunidades aquáticas e efluentes líquidos. São Paulo: CETESB; Brasília: ANA; 2011.

Fernandes Filho EI et al., editors. Mapa de solos do estado de Minas Gerais. Belo Horizonte: Fundação Estadual do Meio Ambiente; 2010.

Fernandes GW, Goulart FF, Ranierid BD, Coelho MS, Dales $\mathrm{K}$, Boescheg $\mathrm{N}$ et al. Deep into the mud: ecological and socioeconomic impacts of the dam breach in Mariana, Brazil. Natureza \& Conservação 2016; 14: 35-45. 10.1016/j.ncon.2016.10.003

Garcia GE, Gonçalves JE. Implementação de modelo numérico para avaliação do transporte de sedimentos no reservatório de Itaipu - PR. Revista Brasileira de Recursos Hídricos 2011; 16(3): 49-58. 10.21168/rbrh.v16n3.p49-58

Gonçalves IS, Dias HCT, Martins SV, Souza AL. Fatores edáficos e as variações florísticas de um trecho de mata ciliar do rio Gualaxo do Norte, Mariana, MG. Revista Árvore 2011; 35(6): 1235-1243. 10.1590/S0100-67622011000700010

Guerra MBB, Teaney BT, Mount, BJ, Asunskis DJ, Jordan BT, Barker RJ et al. Post-catastrophe analysis of the Fundão Tailings dam failure in the Doce River system, Southeast Brazil: potentially toxic elements in affected soils. Water Air Soil Pollution 2017; 228(7): 252. $10.1007 / \mathrm{s} 11270-017-3430-5$ 
Instituto Brasileiro do Meio Ambiente e dos Recursos Naturais Renováveis - Ibama. Laudo técnico preliminar: impactos ambientais decorrentes do desastre envolvendo o rompimento da barragem de Fundão, em Mariana, Minas Gerais [Internet]. 2015 [cited 2016 June 20]. Available from: https://bit.ly/2XmL0RV

Kabata-Pendias A. Trace elements in soils and plants. 4th ed. New York: Taylor \& Francis; 2011. 505 p.

Kemker C. Stream flow and turbidity are often directly related. Environmental measurements [Internet]. 2014 [cited 2016 July 7]. Available from: http://www.fondriest.com/environmentalmeasurements/wp/content/uploads/2014/06/480x195xturbidity_ streamflow.jpg.pagespeed.ic.3561OncUTC.jpg

Lacaz FAC, Sousa Porto MF, Pinheiro TMM. Tragédias brasileiras contemporâneas: o caso do rompimento da barragem de rejeitos de Fundão/Samarco. Revista Brasileira Saúde Ocupacional 2017; 42:49. 10.1590/2317-6369000016016

Magalhães DP, Ferrão Filho AS. A ecotoxicologia como ferramenta no biomonitoramento de ecossistemas aquáticos. Oecologia Brasiliensis 2008; 12(3): 355-381.

Medeiros PRP, Knoppers BA, Souza WFL, Negri E. Aporte de material em suspensão no baixo rio São Francisco (SE/AL), em diferentes condições hidrológicas. Brazilian Journal of Aquatic Science and Technology 2011; 15(1): 42-53.

Meng W, Zhang N, Zhang Y, Zheng B. Integrated assessment of river health based on water quality, aquatic life and physical habitat. Journal of Environmental Sciences 2009; 21(8): 1017-1027. 10.1016/ s1001-0742(08)62377-3

Mendes TA, Fagundes AKB, Pereira TSR. Classificação preliminar de corpos d'água com base na resolução Conama n 357/2005: Caso do rio Meia Ponte - GO. Ciência e Natura 2016; 38(3): 1382-1393. 10.5902/2179460X21832

Minas Gerais. Sistema Estadual de Meio Ambiente. Instituto Mineiro de Gestão das Águas. Encarte especial sobre a qualidade da água do Rio Doce após o rompimento de barragem da Samarco no distrito de Bento Rodrigues [Internet]. 2015a [cited 2016 Mar. 16]. Available from: https://bit.ly/2C5DuPC

Minas Gerais. Sistema Estadual de Meio Ambiente. Instituto Mineiro de Gestão das Águas. Monitoramento da qualidade das águas superficiais do rio Doce no estado de Minas Gerais. Relatório de 17 de novembro de 2015 [Internet]. 2015b [cited 2016 Mar. 16]. Available from: https://bit.ly/2WydqWV

Oliveira BSS, Cunha AC. Correlação entre qualidade da água e variabilidade da precipitação no sul do estado do Amapá. Revista Ambiente \& Água 2014; 9(2): 261-275. 10.4136/ambi-agua.1287

Oliveira LCF, Salgado OA. As regiões fitoecológicas, sua natureza e seus recursos econômicos, estudo fitogeográfico. In: Projeto
RADAMBRASIL: Folha SE, Rio Doce: Levantamento de Recursos Naturais. Vol. 34. Rio de Janeiro: IBGE; 1987. p. 353-416.

Parra RR, Roeser HMP, Leite MGP, Nalini HA Jr, Guimarães ATA, Pereira JC et al. Influência antrópica na geoquímica de água e sedimentos do rio Conceição, quadrilátero ferrífero, Minas Gerais - Brasil. Geochimica Brasiliensis 2007; 21(1): 036-049. 10.21715/ gb.v21i1.255

Rodrigues ASL, Malafaia G, Costa AT, Nalini HA Jr. Adequação e avaliação da aplicabilidade de um Protocolo de Avaliação Rápida na bacia do rio Gualaxo do Norte, Leste-Sudeste do Quadrilátero Ferrífero (MG, Brasil). Revista Ambiente \& Água 2012; 7(2): 231244. 10.4136/ambi-agua.872

Rodrigues ASL, Nalini HA Jr, Costa AT, Malafaia M. Construção de mapas geoquímicos a partir de sedimentos ativos de margens oriundos do Rio Gualaxo do Norte, MG, Brasil. Multi-Science Journal 2015; 1(1): 70-78. 10.33837/msj.v1i1.50

Schaefer CEGR, Santos EE, Fernandes Filho EI, Assis IR. Paisagens de lama: Os Tecnossolos para recuperação ambiental de áreas afetadas pelo desastre da barragem do Fundão, em Mariana. Boletim informativo Sociedade Brasileira de Ciência do Solo 2016; 42(1).

Schaefer CEGR, Santos EE, Souza CM, Damato Neto J, Fernandes Filho EI, Delpupo C. Historical scenario, physiography and strategies for environmental rehabilitation of the landscape affected by the Fundão Dam breaking accident at Mariana, Minas Gerais State. Arquivos do Museu de História Natural e Jardim Botânico 2017; 24(1): 104-135.

Silva APS, Dias HCT, Bastos RKX, Silva E. Qualidade da água do reservatório da usina hidrelétrica (UHE) de Peti, Minas Gerais. Revista Árvore 2009; 33(6): 1063-1069. 10.1590/S010067622009000600009

Smichowski P, Marrero J, Gómez D. Inductively coupled plasma optical emission spectrometric determination of trace element in $\mathrm{PM}_{10}$ airborne particulate matter collected in an industrial area of Argentina. Microchemical Journal 2005; 80(1): 9-17. 10.1016/ j.microc.2004.07.023

Sutton AJ, Fisher TR. Historical changes in water quality at German Branch in choptank river basin. Water, Air and Soil Pollution 2009; 199(1-4): 353-369. 10.1007/s11270-008-9884-8

Thomaz EL, Antoneli V, Dias WA. Estimativa de proveniência de sedimento em cabeceira de drenagem com alta densidade de estradas rurais não pavimentadas. Revista Brasileira de Recursos Hídricos 2011; 16(2): 25-37. 10.21168/rbrh.v16n2.p25-37

United States. Environmental Protection Agency. Microwave assisted acid digestion of sediments sludge, soils, and oils 2007. Technical Resource Document, EPA SW 846 3051a. 30 p. 